\title{
Introduction Part 1 - Critical Themes, Geopolitical Change and Global Contexts in Contemporary Asian Art
}

\author{
Caroline Turner
}

This book explores cultural connections and intersections that are related to the dynamic changes in art in Asia in the late twentieth and early twenty-first centuries. It derives from an Australian Research Council (ARC) funded research project (Turner and Antoinette 2010-2013) examining new cultural networks in contemporary Asian art in the twenty-first century with a central theme of 'connectivities', from which this volume of essays takes its title. ${ }^{1}$ The four key themes of this book, which are outlined below, are drawn from this research.

The focus of our research is contemporary Asian art, broadly defined as the art of the last 25 years. The essays in this volume provide significant new insights into contemporary art and institutions in the Asian region and into unfolding discourses in Asian art. A number of the essays are by Asian authors, thus providing important perspectives from the region, and the contributors include curators as well as scholars undertaking research in the areas of art history and contemporary visual culture.

\section{Themes of the Book}

In 2011 I was asked by Dr Debjani Ganguly, Head of the Humanities Research Centre (HRC) at The Australian National University (ANU), to convene a conference on art (with Michelle Antoinette, Zara Stanhope and Jackie Menzies) addressing the broad concept of 'the world and world-making'. That conference was planned to intersect with two other HRC conferences convened by Ganguly, one on world literature and one on history, the latter being 'Subaltern Studies: Historical World-making Thirty Years On', co-convened by Dipesh Chakrabarty, a long-term colleague and Adjunct Professorial Fellow at the HRC. Both Chakrabarty's groundbreaking book, Provincializing Europe: Postcolonial

\footnotetext{
1 Caroline Turner and Michelle Antoinette, 'The Rise of New Cultural Networks in Asia', Australian Research Council Discovery Grant (DP 1096041).
} 
Thought and Historical Difference, and Ganguly's conceptualisation of the three conferences have been extremely influential in shaping the first theme of this current volume of essays - 'world-making'. ${ }^{2}$

The keynote papers delivered by Patrick Flores and John Clark at the conference 'The World and World-Making in Art: Connectivities and Differences', are published in this volume. In all, nine authors in this volume gave papers and participated in discussions at the conference (Flores, Clark, Sambrani, Hoffie, Merewether, Meskimmon, Maravillas, Antoinette and Turner). ${ }^{3}$

The second, third and fourth themes of this book have also emerged, as indicated above, from research for our ARC grant on new cultural networks in Asia. These are: intra-Asia regional connections, Australia's cultural interconnections with Asia and, lastly, art's empathetic effects in cross-cultural engagement.

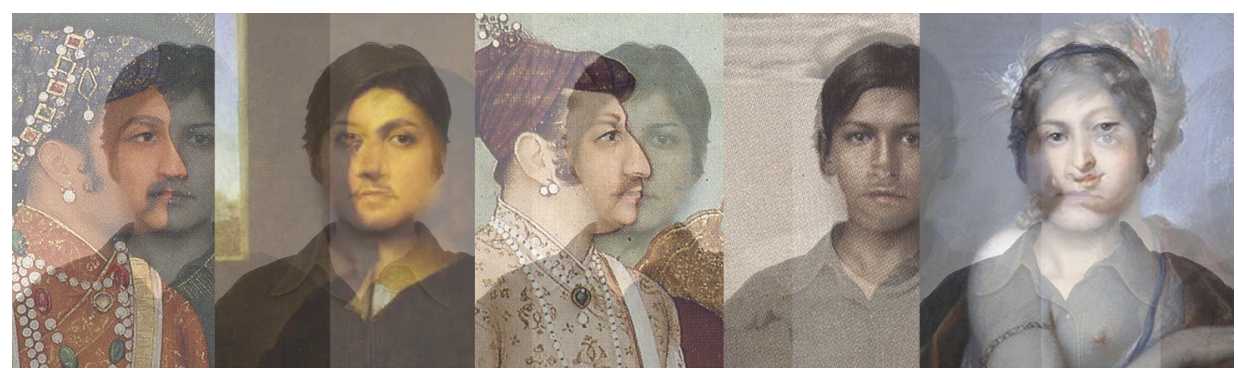

Nusra Latif Qureshi, Did you come here to find history? 2009 (detail); digital print. This work was shown in the 53rd Venice Biennale and in the exhibition 'Beyond the Self: Contemporary Portraiture from Asia', curated by Christine Clark and exhibited at the National Portrait Gallery, Canberra, and regional venues in Australia 2011-2013. The artist was an invited speaker at the conference 'The World and World-Making in Art', Humanities Research Centre, The Australian National University, Canberra, 2011. See www.portrait.gov.au/site/exhibition _ subsite _ beyondtheself artist.php?artistID $=14$

Image courtesy Nusra Latif Qureshi and the National Portrait Gallery of Australia

\footnotetext{
2 Dipesh Chakrabarty, Provincializing Europe: Postcolonial Thought and Historical Difference (Princeton University Press, 2000). See also hrc.anu.edu.au/events/subalternstudies

3 'The World and World-Making in Art', conference, Humanities Research Centre, The Australian National University, 11-13 August 2011. Convened by Caroline Turner, Michelle Antoinette, Zara Stanhope and Jacqueline Menzies. See also Turner, Antoinette \& Stanhope eds, 'The World and World-Making in Art', Humanities Research 19, no. 2 (2013), epress.anu.edu.au/titles/humanities-research-journal-series/volumexix-no-2-2013
} 

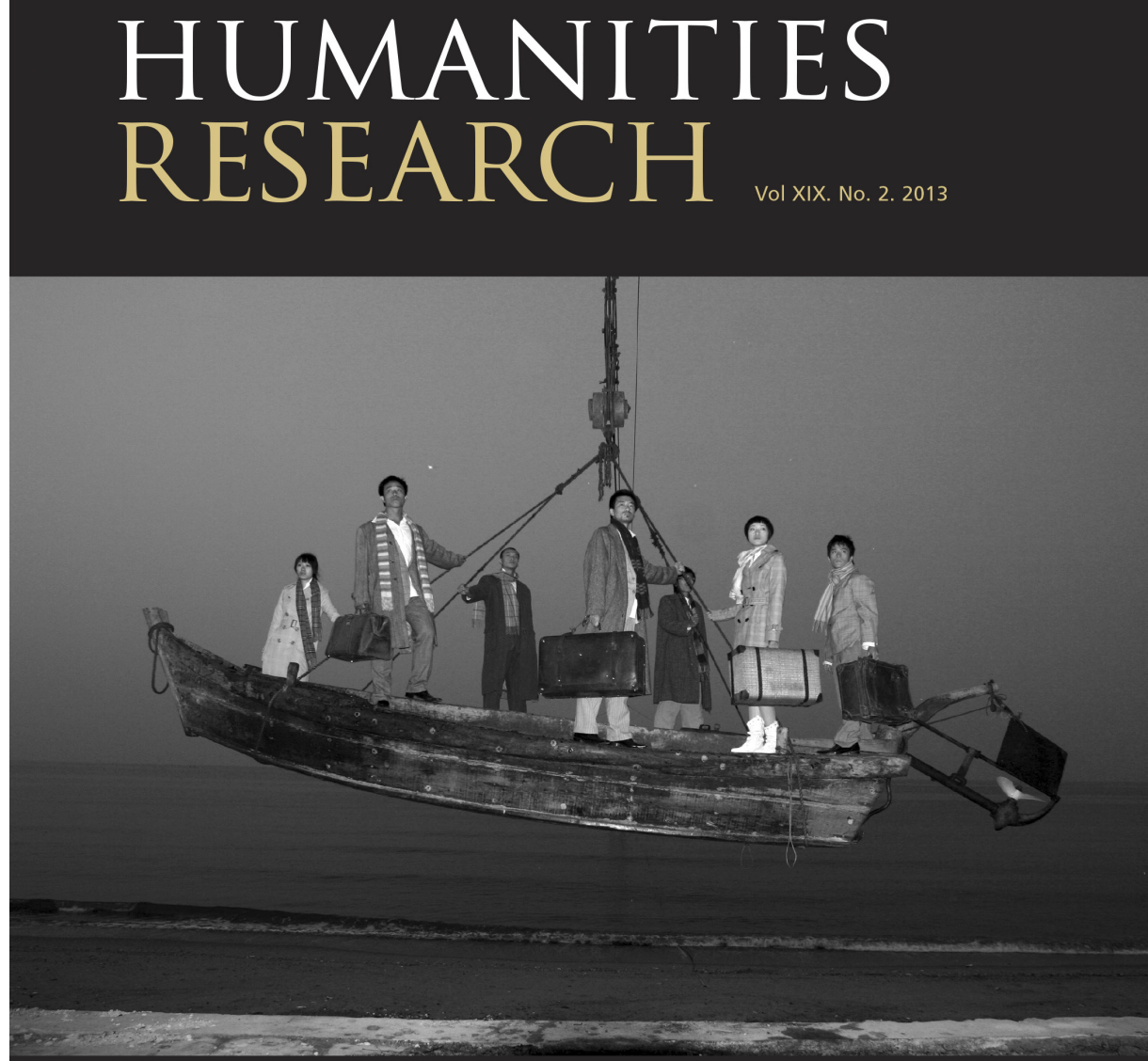

\section{THE WORLD AND WORLD-MAKING IN ART}

Cover of The World and World-Making in Art, special issue, Humanities Research 19, no. 2, 2013, edited by Caroline Turner, Michelle Antoinette \& Zara Stanhope; featuring artwork by Yang Fudong, Seven Intellectuals in Bamboo Forest, Part IV 2004; photograph: black \& white C-print; $120 \times 180 \mathrm{~cm}$; edition of 10 . 
These four themes underpin this volume of essays. Our Introduction (Turner and Antoinette), is separated into two essays that outline the themes and issues and analyse historical and present developments in contemporary Asian art. The following essays by Flores and Clark offer further 'mapping' of Asian art and broad theoretical and conceptual approaches; Chaitanya Sambrani provides a case study of a specific exhibition, as does Pat Hoffie. Both also examine the critical issue of defining the 'contemporary' in art practice in Asia. Charles Merewether, Marsha Meskimmon and Francis Maravillas explore the inspiration and aesthetic contexts of the work of a number of Asian artists; Oscar Ho and Alison Carroll evaluate museum, curatorial and cultural agency approaches to intra-Asian networks, while Jacqueline Lo's essay illuminates Australia's engagement with Asia with special emphasis on Asian-Australian contributions. Michelle Antoinette provides an Epilogue and final essay to the volume.

This essay introduces the critical themes and contexts of this book and of the essays that follow within the broad framework of Asia and Asian art in a transforming world. I evaluate, in particular, the impact of geopolitical change and its effects on art and culture in the region, and also give an overview of some of the exhibitions and conferences that have helped shape the discourses about art in the Asian region over the last 25 years. I do so writing as a participant in many of these events. I also briefly discuss Australian cultural intersections with Asia in the same period. In the second part to this Introduction, Antoinette further elaborates each author's contribution in relation to our themes and to the overarching concept of 'connectivities'.

\section{Contemporary Asian Art: Geopolitical and Economic Change}

A critical question that has preoccupied those working in the field of Asian art is 'What is contemporary Asian art?' The Japan Foundation posed this question in the cross-cultural and transnational curatorial and exhibition project 'Under Construction: New Dimensions in Asian Art' conducted between 2001 and $2003 .{ }^{4}$ Contemporary art from Asian countries is now seen in major international exhibitions around the world, but this is a relatively new phenomenon that parallels developing geopolitical and economic relationships. As other contributors indicate, art was dramatically transformed by the late twentieth century process of globalisation and geopolitical change that led to

\footnotetext{
4 'Under Construction: New Dimensions in Asian Art', Japan Foundation Forum 2002, convened by Yasuko Furuichi www.jpf.go.jp/e/culture/new/old/0210/10_07.html (accessed 3 August 2013). The exhibition was curated by nine curators from seven Asian countries. For other Japan Foundation contributions see, for example, Japan Foundation, ed., Asia in Transition: Representation and Identity, The Japan Foundation 30th Anniversary International Symposium 2002 (Tokyo, 2002).
} 
a shift from an art centred in Europe and America and towards regions such as Asia. The higher visibility of contemporary Asian art in world exhibitions and forums in recent times needs to be seen in terms of a global expansion of interest in art beyond the art centres of Europe and North America. At the same time, no consideration of contemporary Asian art can be divorced from the tremendous political and economic changes in the region itself over the last two decades. As I have argued elsewhere, Asian contemporary art is under construction in an alternative sense - that is, the region is helping create a new framework for global art expressions. ${ }^{5}$

Geopolitical and economic transformations have led to an unprecedented growth in the middle classes in Asia, the lifting of hundreds of millions of people out of poverty, increased educational and other opportunities, revitalised intra-Asian interactions and new globalised connectivities, but at the same time, an increased consumerism and materialism and societies in which huge inequities and social issues remain to be resolved. Geeta Kapur, one of the pre-eminent writers on art today, describes the context for Indian (and by extension) many Asian artists as 'a civil society in huge ferment, a political society whose constituencies are redefining the meaning of democracy and a demographic scale that defies simple theories of hegemony' ${ }^{6}$

The astonishingly rapid transformations in Asia in the last 25 years have led analysts to refer increasingly to the twenty-first century as 'the Asian century'. As Australian academic Glen Barclay has noted:

The tectonic plates are shifting: what political philosopher Carl Schmitt called the 'identity of the period' of the last century, was the movement of the balance of world influence westward across the Atlantic from Europe to the United States. What will provide the identity of this century is the continuing westward movement of that balance across the Pacific to its logical locus, the home of more than three billion people, more than half the population of the world. ${ }^{7}$

This situation is described by Singaporean Kishore Mahbubani, formerly a diplomat and now Dean of the Lee Kuan Yew School of Public Policy at the National University of Singapore, as a case of the world returning to the historical normality of the place of Asian societies in the global hierarchy. ${ }^{8}$ Significantly for one theme of this volume, that of intra-regional connections, Mahbubani

5 Turner, ed., Art and Social Change: Contemporary Art in Asia and the Pacific (Canberra: Pandanus Books, 2005).

6 Geeta Kapur, 'Dismantled Norms: Apropos other Avantgardes', in Tradition and Change, ed. Caroline Turner (St Lucia: University of Queensland Press, 1993), 97.

7 Glen Barclay, 'Geopolitical Changes in Asia and the Pacific', in Art and Social Change, 15.

8 Kishore Mahbubani, The New Asian Hemisphere, The Irresistible Shift of Global Power to the East (New York: Public Affairs, 2008). 
also sees new connectivities as having the potential to lead to shared values and aspirations in the Asian region, mediating old rivalries and tensions that remain evident today.

Many of the artists who have come to international prominence in Asia in recent decades have done so as the region changed. For example, Japanese artists were included in major international exhibitions beginning in the 1960s and 1970s, at the time when the Japanese economy became the second largest economy in the world, although it has now been surpassed by China and has since dropped to third place. It is without question that China's extraordinary economic rise in recent times has led to world attention being focused on Chinese artists, many of whom are now superstars of the international art world. What is occurring is far more than artists from the so called 'periphery' being admitted to a 'canon' of art controlled by the West. There has been recognition for some time that Western art historical approaches cannot be the only framework for understanding and interpreting contemporary art developments in Asia. A new framework for art needs to include what Ho refers to in this volume as the development of 'languages outside a Western-dominated art world'.

Art historian Terry Smith, one of the speakers at our world-making conference, has pointed to the historical shift from Euro-American geopolitical and economic hegemony over the last 50 years. This shift has occurred, he notes, at an accelerated pace in recent years and is now affecting the context for art: 'Geopolitical change has shifted the world picture from presumptions about the inevitability of modernisation and the universality of EuroAmerican values to recognition of the coexistence of difference, of disjunctive diversity, as characteristic of our contemporary condition. ${ }^{9}$ Smith has also argued that '... contemporary art is perhaps for the first time in history - truly an art of the world' ${ }^{10}$ In Asia this phenomenon has led to challenges to Euro-American values and dominance in art and is a concept that emerges strongly across the essays in this volume.

Art historian Michael Sullivan, writing in 1989, noted that the rapid flow of art and ideas from culture to culture today is now so extensive that it is no longer regarded with surprise. ${ }^{11}$ In 1993 historian Wang Gungwu wrote that: 'The modern world has made people aware of similarities and differences

9 Terry Smith, 'Worlds Pictured in Contemporary Art: Planes and Connectivities', in 'The World and World-Making in Art', 12. See also Smith, 'Currents Of World-Making in Contemporary Art', World Art, no. 2 (2011): 20-21.

10 Smith, conference abstract for 'The World and World-Making in Art', Humanities Research Centre, ANU, 2011. See also Smith, Contemporary Art: World Currents (London: Laurence King and Thames \& Hudson; Upper Saddle River, NJ: Pearson/Prentice Hall, 2011). For further discussion of the global in art see, for example, Hans Belting, 'Contemporary Art as Global Art: A Critical Estimate', in The Global Art World: Audiences, Markets, and Museums, ed. Hans Belting \& Andrea Buddensieg (Ostfildern: Hatje Cantz, 2009), 38-73.

11 Michael Sullivan, The Meeting of Eastern and Western Art (Berkeley: University of California Press, 1989), 4. Sullivan describes the active dialogue between what he calls 'Eastern' art with Western beginning after 1500 , but notes that there had been cultural exchanges long before that date. 
among themselves to an extent never dreamed of in the past. Being thus more aware, people can never be the same again'. ${ }^{12}$ The exchange of ideas that Sullivan and Wang Gungwu referred to has become more rapid, especially as new technologies, including the internet and social media, greatly expand connectivities. Globalisation has generated new debates about differences, similarities, parallel histories, art histories and art practices that necessitate multifaceted responses, as the essays in this volume reveal.

In geocultural terms the idea of 'Asia' itself is problematic, as the title of the 'Under Construction' project suggested. Asia is no monolithic entity. The idea of 'Asia' has been to a degree, as many scholars have suggested, a constructed discourse partly developed in counterpoint to the idea of the 'West', and one that cannot be used to deny the diversity of local cultures and histories in the region. It is also true, as Thai art historian Apinan Poshyananda noted when writing about Thailand, that syncretism has been a key factor in historical cultural formations in the region. ${ }^{13}$ The influence of fountainhead cultures, such as India and China, in historical times has been significant and Japan has been a major influence in interconnections with the West since the Meiji Restoration in the nineteenth century. Encounters with Western countries had a major impact, but we need to recall that not all Asian countries were colonised and that anticolonial struggles in Asia have a long history. While it is clear from the essays in this volume that local, national and regional histories as well as contemporary political and social changes within countries have impacted with tremendous force on art practice, there is equally the effect of dynamic cultural engagement regionally and globally which transcends simple global/local dichotomies. These extend to minorities and multiculturalism within nations, hybridity and multiple identities, mobilities that transcend past histories and national borders, and new and extended global interactions in terms of individual lives. As Singaporean academic Lily Kong has commented: 'The reality is that our lives [today] are shaped by both the global and the local, the transnational and the nation' ${ }^{14}$

Some of the dramatic changes evident across Asia in our times can be seen in 'West Heavens', the contemporary art and intellectual exchange between artists from India and China, which is one of the first major art exchanges between these two nations in recent times. 'West Heavens' is the initiative of Hong Kongbased Johnson Chang (Chang Tsong-Zung). ${ }^{15}$ In ancient Chinese Buddhist texts,

\footnotetext{
12 Wang Gungwu, 'Foreword', in Tradition and Change, vii.

13 Apinan Poshyananda, 'The Development of Contemporary Art of Thailand: Traditionalism in Reverse', in Tradition and Change, 93-100.

14 Lily Kong, 'Asian Studies and/in Asian Universities: Global Impacts?', keynote address, Asian Studies Association of Australia (ASAA) 19th Biennial Conference, 11 July 2012.

15 See Chang Tsong-Zung, 'Introduction', unpaginated exhibition booklet, 2010, and website http:// westheavens.net/en/ (accessed 18 January 18, 2011). The 'West Heavens' project has been awarded the first Art Newspaper Asia Prize (2014) created in celebration of the first anniversary of the Chinese edition of the Art Newspaper.
} 
India was referred to as the 'West Heavens' and was the source of Buddhist ideas. The project seeks to continue this centuries old 'cultural dialogue' and to 'compare the different paths of modernity taken by India and China'. In 2012 an exhibition Place.Time.Play: Contemporary Art from the 'West Heavens' to the 'Middle Kingdom', representing artists from both nations, was held in Shanghai as part of the project. It was curated by Sambrani, who provides a fascinating personal perspective on developments in art in the region and a curator's insights into the ways the artists explored artistic connectivities and transnational cultural dialogue.

Mumbai artist Tushar Joag based his art installation in that exhibition on a performance entitled Riding Rocinante that involved his riding a motorcycle for 53 days from Mumbai to Shanghai. The clothes he wore on the trip and the disassembled motorcycle were used in the installation after being symbolically washed in the waters of the Yangtze, Asia's longest river and the site of the Three Gorges dam, discussed by Merewether, Sambrani and Antoinette. Joag's journey reversed those of Chinese Buddhist pilgrims Faxian (399 and $412 \mathrm{CE}$ ) and Xuanzang (seventh century CE) who went to India seeking sacred texts. It also referenced the journey of renunciation that the Buddha took on his horse Kanthaka, Don Quixote's journeys on his horse Rocinante in the early seventeenth century in Spanish writer Miguel de Cervantes' novel Don Quixote and, of course, the twentieth century motorcycle adventure of self-discovery undertaken by Latin American revolutionary Che Guevara. This artwork is, therefore, a reminder of the global interchange of ideas that characterises so much Asian art today. Joag, who has undertaken a number of art projects related to social issues in India, also wished to highlight the plight of those in both nations displaced by massive new industrial projects, such as the Sardar Sarovar Dam in India and Three Gorges dam on the Yangtze in China. These issues are also being explored by artists in China, for example, as Merewether discusses in analysing the art projects, and motivations for those projects in relation to water, of Zhuang Hui, Chen Qiulin, and Liu Xiaodong, which focus on the Yangtze.

Joag's work serves to highlight critical ideas in our research project that are explored in this volume, including globalisation and an increasing exchange of knowledge and ideas in intra-Asian contexts. As well as the dramatic geopolitical and economic transformations referred to above, his artwork reveals the effects of rapid industrialisation, including the growth of mega cities - such as Mumbai and Shanghai-and subsequent dislocation of large numbers of people as a direct result of rapid industrialisation and urban growth, and the way that artists in Asia are addressing social change. 


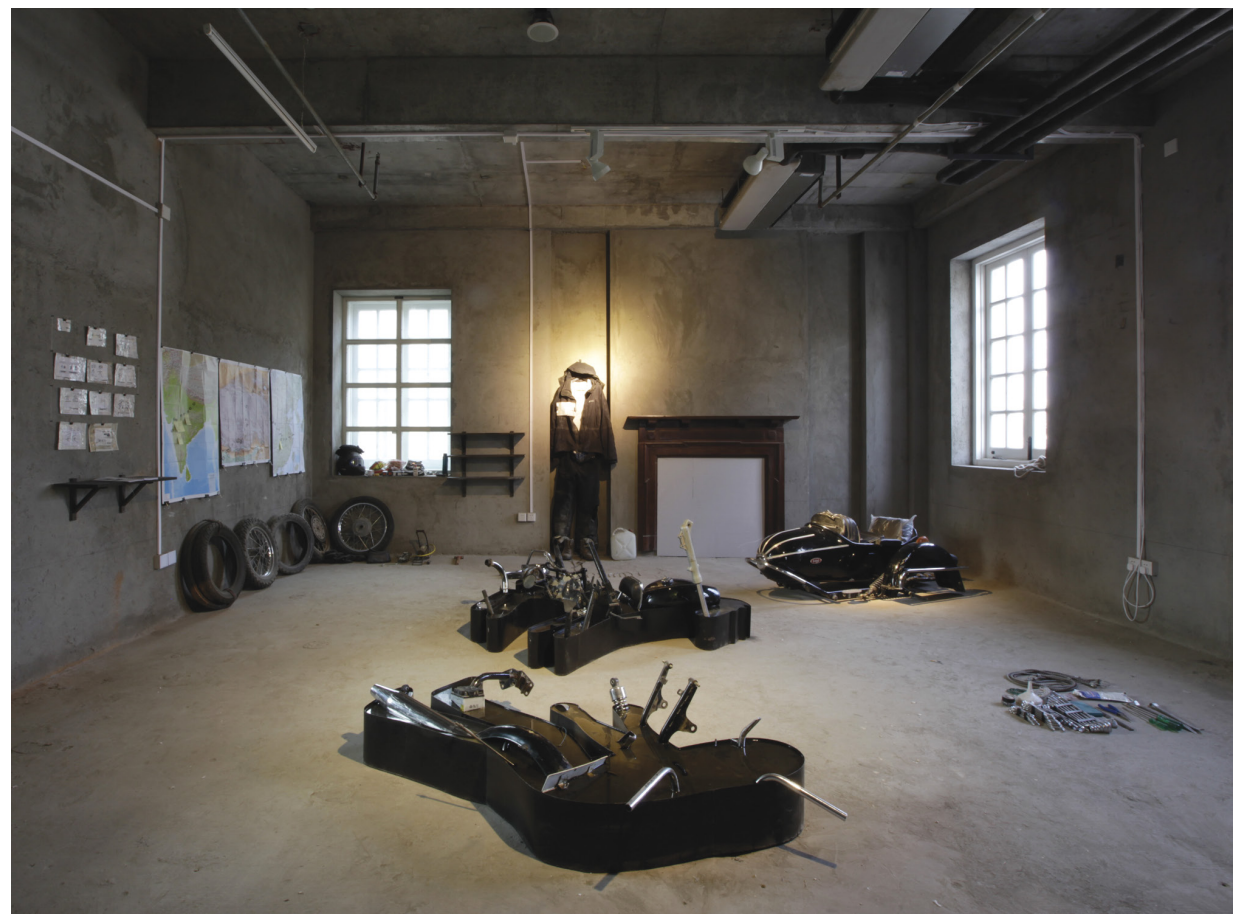

Tushar Joag, Background: Riding Rocinante: from Bombay to Shanghai via Sardar Sarovar and the Three Gorges 2010; maps, motorcycle spare parts and tools; dimensions variable. Foreground: The Realisation of Kanthaka 2010; sculptural installation; 152.4 × $100 \times 365 \mathrm{~cm}$.

Photograph: Thomas Fuesser; image courtesy of Tushar Joag and West Heavens

\section{Contextualising the 'Contemporary' in Asian Art Discourses}

The idea of an 'Asian' art is in part a Western classification and in part a construction developed in the countries that make up the continent. There are three critical time periods used in discourses about Asian art. First, historical or classical Asian art, which is seen and admired in museums around the world and which is generally art produced from ancient times up to the nineteenth century, but sometimes encompasses 'traditional' practice beyond that date (see Hoffie, this volume). Secondly, it is necessary to take into account the 'Asian Modern', discussed by Clark, which extends from the nineteenth century to the early 1990s. The third period is that of 'contemporary' Asian art, usually regarded as beginning in the late 1980s and early 1990s. As Sambrani points out, there is a sophisticated tradition of art scholarship in Asia, but until recently, art was 
largely viewed within national contexts, although links between scholars and artists existed well before the contemporary era-for example, between India and Japan.

Flores and Clark, among others, have made enormous contributions to debates about art in Asia over recent decades. Their key essays encapsulate the necessity of wider and richer historical and theoretical perspectives than those of the last 25 years. This point has also been made by other prominent scholars in the region, for example by leading Singapore art historian, T.K. Sabapathy, who also points to the need for an historical dimension in interpreting contemporary art in the region. ${ }^{16}$

In this volume Flores, who is a major figure in defining the 'contemporary' in Asian art and its place in global art debates, looks at the concept of 'world-making' by setting the Philippines in the context of colonial and postcolonial Spanish and American imperialism, postwar independence and the shifting political, social and economic realities of our world today. He shows the complexities for Filipinos of moving between local and global societies (historically and more recently), the often migratory economic realities that dictate life in the Philippines, and the condition of 'mediating discrepant worlds coming together in an instance that is at once belated and present .... ${ }^{17}$

The idea of the 'contemporary' has been resisted by some art historians, who see the contemporary as the domain of art criticism. As art historian Miwon Kwon notes: 'Contemporary art history ... marks a temporal bracketing and a spatial encompassing, a site of a deep tension between very different formations of knowledge and traditions, thus a challenging pressure point for the field of art history in general'.${ }^{18}$ Clark points to '... the still largely absent discourse of a worlded art history that takes account of Asia'. I would argue, however, that this is changing. The issue of whether art history can be truly global is a significant new area in art history scholarship, as evidenced by papers, including by Clark, in a session at a recent major conference in Germany in 2012. ${ }^{19}$

16 See T.K. Sabapathy, 'Developing Regionalist Perspectives in South-East Asian Art Historiography', Second Asia-Pacific Triennial (Brisbane, 1996), 13-17. Sabapathy elucidates the strong links in South-East Asia over the millennia and in the anti-colonial struggles between Indonesia, Malaysia and Singapore forged in the 1940s and 1950s and also cites leading Indonesian scholar Jim Supangkat's 'insistence that modernism should be "recontextualised"' (1996: 13). On the continuing need for an historical perspective, see also Sabapathy, ed., Intersecting Histories: Contemporary Turns in Southeast Asian Art (Nanyang Technological University, 2012).

17 Flores is the author of numerous influential articles and several books concerning Philippine art and the curator of major projects; see, for example, Flores, 'Position Papers: Turns in Tropics: Artist-Curator', in The 7th Gwangju Biennale: Annual Report: A Year in Exhibitions, ed. Okwui Enwezor (Gwangju Biennale Foundation, 2008), 262-85, and T.K. Sabapathy, Patrick D. Flores \& Niranjan Rajah eds, 36 Ideas from Asia: Contemporary South-East Asian Art (Singapore Art Museum, 2002). (See also Author Biography.)

18 Miwon Kwon, OCTOBER 130 (Fall 2009): 13.

19 The 33rd Congress of the International Committee of the History of Art (CIHA), 15-20 July 2012, Nuremberg, Germany. See http://www.ciha2012.de/en/home.html. The conference session was convened by 
Clark has been one of the leading voices in drawing the distinction between the 'Asian Modern' and 'contemporary' art. In a series of seminal publications he has defined the histories and 'multiple art discourses' and practices in what he refers to 'as a particular set of geographically defined entities, which became the modern state system in Asia from the onset of late Euramerican colonialism in the eighteenth century until the end of colonial rule in the mid-twentieth century'. His essay looks in particular at the transfer of art and ideas across the region within this timeframe.

Clark's groundbreaking 1991 conference at the HRC, 'Modernism and Postmodernism in Asian Art', was the first such international conference held in a Western country. It opened up critical debates by bringing together art historians from across Asia to present developments in their different nations, on the 'Asian Modern' in particular, thus opening up new possibilities of comparative regional and transnational art histories. ${ }^{20}$ This framework of comparative national art histories has been energetically developed since that time by scholars and curators in the region. Jim Supangkat, T.K. Sabapathy, Redza Piyadasa, Geeta Kapur, Gulammohammed Sheikh, Salima Hashmi, Apinan Poshyananda, Somporn Rodboon, Akira Tatehata, Fumio Nanjo, Eriko Osaka, Hou Hanru, Wu Hung, Gao Minglu, Kim Youngna, Soyeon Ahn, Alice Guillermo and Patrick Flores, among others, have been at the forefront of exploring the legacies of the historical and more recent past. Scholars outside Asia have also made significant contributions. These include authors in this volume and those whose work engages with the modern art history of individual countries, such as Astri Wright (Indonesia), Britta Erickson (China), Nora Taylor (Vietnam), Alexandra Munroe (Japan), and others cited in 'Selected Reading on Contemporary Asian Art' in this volume. ${ }^{21}$ While much debate is focused on contemporary art, it has long been realised that there is a need to link the historical and modern art history of the region to its contemporary art. Further, the idea that is now broadly accepted in the international art world of 'multiple modernities', and of the 'multiple art discourses' and practices that characterise the modern referred to by Clark, has changed the cultural landscape for art globally and led to challenges to the suggestion earlier made by some Western art critics at Clark's 1991 conference, that the 'modern' art of Asia (and elsewhere outside the West) was merely 'derivative' of Western art.

Australian art historian Jaynie Anderson, another speaker at the 'World and World-Making' conference. Anderson has been President of CIHA, which will hold its next world congress in 2016 in Beijing - a significant step toward developing an art history that encompasses Asia.

20 See also John Clark, Modern Asian Art (Sydney: Craftsman House, 1998).

21 See citations in footnote references elsewhere in this book, as well as 'Selected Reading on Contemporary Asian Art' in this volume; essays by Salima Hashmi, Geeta Kapur, Redza Piyadasa, Jim Supangkat, Masayoshi Homma, Alice Guillermo, Nguyen Quan, Xu Hong, T.K. Sabapathy, Apinan Poshyananda in Tradition and Change; and by these and other authors, such as Jagath Weerasinghe, Somporn Rodboon, Yulin Lee, Soyeon Ahn and Dang Thi Khue in Art and Social Change. 
By contrast, the essays in this volume reinforce the distinctiveness of Asian art and art histories and the distinctive voices of art experts in Asia who are shaping this new field of scholarship.

The Asian region has continued to develop its own forums for art and creative dialogue between artists, curators, and scholars. The 1990s witnessed a rethinking of cultural frameworks and hegemonies, and critiques of what then was often referred to as the 'Euro-American paradigm'. Over the next decade and into the new century new definitions of 'contemporary' Asian art were tested in various fora, including conferences, symposia, exhibitions and publications, in the region and beyond. The Japan Foundation has been a leader in these debates, as has the New York-based Asia Society. In the Australian context the conferences held in 1993, 1996 and 1999 in association with the Asia-Pacific Triennial of Contemporary Art (APT) exhibitions were also important early platforms for connecting to Asian discourses, especially for Australian artists and curators.

In referring to the $1993 \mathrm{APT}$, Hoffie draws attention to the dilemmas of defining the 'contemporary' by noting the shift that occurred 'in the understanding of the term "contemporary" as it was understood within the many accounts of the post-postmodern/postcolonial world of "international" art theory that was emerging from north of the equator', and how this 'signified cooler shifts into newness; a term that was not tied to any of the messy, resistant (often wilfully resistant) ballast of the past'. The APT exhibitions reflected this, she argues, in that the first triennial:

... made the potentially radical proposal by suggesting, in this region at least, the 'contemporary' had not emerged mysteriously as a weightless and shadowless ghost of the eternal now, but as a force that had developed through different forms in accordance with different circumstances and in relation to particular contexts. Rather, it was presented as an active, contested zone of conflict, contrapuntals, contradictions, productive confusions, contrarieties and contrasts.

Here, I suggest, context is critical: art in Asia should not be understood by looking only at its engagement with Western art that set art in the region on a new trajectory, or in terms of Western colonialism. For example, a 2007 conference in Guangzhou, China, was entitled 'Farewell to Postcolonialism' and discussions included strongly expressed views that colonialism, the issues of Western colonialism, and Western theories of art grounded in a world view entrenched in ideas about the region viewed from the perspective of colonialism and postcolonialism, were of the past. ${ }^{22}$ Over the last two decades scholars in

22 Sarat Maharaj, one of the curators of the Guangzhou Triennial 2008, entitled Farewell to Postcolonialism, Towards a Post-Western Modernity, for which the conference was a precursor, noted in 2007 the difficulty for a South African-born scholar of Indian descent to 'farewell' postcolonialism (author observations at conference). 
Asia have examined the links between art and geopolitical change, and art and globalisation in relation to theories of art emerging from the West, as in the Japan Foundation conference 'Count 10 Before You Say Asia-Asian Art after Postmodernism' (Tokyo, Japan, 2008), at which Flores was a lead speaker. The description for the latter conference noted that: 'The integration of non-western contemporary art into the global art scene in the past 20 or so years has been rapid and explosive', but went on to suggest:

The theoretical frame of postmodernism, proposed within the Western perspective of the modernist impasse, accelerated this process of integration in the name of multiculturalism and post-colonialism. With the increasing recognition of the possible complicity between this postmodernist discourse and the globalizing tendency of capitalist system and of its possible generation of (degeneration into) 'cosmetic' multi-culturalism, we are now standing at a historical juncture where the necessity [is] to re evaluate the achievements and problems of postmodernist discourse and its effect in relation to Asian contexts ... ${ }^{23}$

Asian art historical studies over the last 25 years have included examinations of specialist areas, such as women artists, ${ }^{24}$ as well as specialist regional studies ${ }^{25}$ and, of course, nationally focused art histories. There have been some attempts at transnational art histories comparing art movements in Asia, such as Asian Modernism, an exhibition organised by the Japan Foundation. ${ }^{26}$

As part of and in tandem with this ongoing process of re-evaluation of what is now critical in Asian art, in the last two decades the Asian region has produced an explosive growth in the exhibition and collecting practices of art museums, the projects of artist-run spaces and initiatives developed outside formal institutions, and development of biennales and other such recurring exhibitions. This is paralleled, as Antoinette underlines, by the emergence of a greatly expanded commercial gallery sector and thriving, indeed booming, art market. Important biennales and triennales in the region, and their beginning dates, include: the Indian Triennial (1968); Bangladesh (1981), Gwangju, South Korea (1995), Shanghai, China (1996) and Taipei, Taiwan (1998), biennales; the APT at the Queensland Art Gallery (QAG) in Brisbane, Australia (1993);

\footnotetext{
23 The conference 'Count 10 Before You Say Asia-Asian Art after Postmodernism' was convened by Yasuko Furuichi; website accessed 26 May 2011, http://www.jpf.go.jp/e/culture/new/0810/10_01.html.

24 See, for example, Dynah Dysart \& Hannah Fink eds, Asian Women Artists (Sydney: Craftsman House, 1996); Britta Erickson, 'The Rise of a Feminist Spirit in Contemporary Chinese Art', Art AsiaPacific, 31 (2001): 65-71; Salima Hashmi, Unveiling the Visible: Lives and Works of Women Artists of Pakistan (Lahore: Sang-iMeel Publications, 2002); Binghui Huangfu, ed., Text and Subtext: Contemporary Art and Asian Women Artists (Singapore: Earl Lu Gallery, 2000).

25 See, for example, Nora A. Taylor \& Boreth Ly eds, Modern and Contemporary Southeast Asian Art: An Anthology (New York: Cornell University, 2012).

26 Tatehata Akira, Mizusawa Tsutomu \& Shioda Junichi eds, Asian Modernism-Diverse Development in Indonesia, the Philippines, and Thailand (Tokyo: The Japan Foundation Asia Centre, 1995).
} 
and the significant Fukuoka Triennale in Japan (1999). The last grew out of earlier, recurring Asian art exhibitions beginning in the late 1970s. In the first decade of this century many more recurrent exhibitions have been held, including the Yokohama, Japan (2001) and Guangzhou, China (2003) triennials; and the Busan, South Korea (2002); Beijing, China (2003); Singapore (2006); Jakarta and Yogyakarta, Indonesia (intermittent); and Kochi-Muziris, India (2012) biennales. The recent World Biennial forum in Gwangju hosted representatives from almost every Asian country, many of which are developing new biennale projects. Indeed there are currently more biennales in Asia than anywhere else in the world. As most of these exhibitions are focused on regional and international art, they have become important sites of engagement and dialogue about contemporary art in Asia and globally. ${ }^{27}$

New cultural networks in Asia have developed in association with such exhibition and museum projects; for example, the Asian Art Museum Directors' network, which is a group of directors of major museums of the region that focus on modern and contemporary art. Singapore, Japan, South Korea and China were critical in the establishment of the network, which holds symposia and works towards the exchange of exhibitions and staff. The seventh meeting was held in Jakarta and Bali in 2013. Curators in Asia have formed a similar network, the Asian Curatorial Network (ACN) (see Ho, this volume). The International Council of Museums (ICOM) has a specific Asia-Pacific branch with networks for staff of every type of museum, and ICOM's modern art committee, CIMAM, has held events in Japan, South Korea and China. As Antoinette notes (Epilogue), the Hong Kong-based Asia Art Archive is a critical source of resource material on modern and contemporary Asian art. As a result of arranging and hosting the APT, QAG has an extensive collection of art, and an archive on that art, from different parts of Asia. The Fukuoka Asian Art Museum in Japan has been collecting for longer and also has a superb collection, while the Singapore Art Museum and the new National Gallery of Singapore are collecting and documenting South-East Asian art in depth. ${ }^{28}$ Singapore has been a key force in intra-Asian art and cultural exchange. South-East Asian art exchanges grew out of Association of Southeast Asian Nations (ASEAN) supported exhibitions and Singapore also has strong links with East Asia. Singapore has taken a lead

\footnotetext{
27 'Shifting Gravity', World Biennial Forum No. 1, Gwangju, Korea, 27-31 October 2012 (http://www. worldbiennialforum.org/), which I attended as an invited speaker, discussed world biennales, but the majority of attendees were from Asia. See Uta Meta Bauer \& Hou Hanru eds, Shifting Gravity: World Biennial Forum No 1 (Hatje Cantz, 2013).

28 See the catalogues of the Asian Art exhibitions, Fukuoka Art Museum to 1999 and catalogues of the first, second and third Fukuoka Asian Art Triennales, 1999 to date. See also, Fukuoka Asian Art Museum, The Birth of Modern Art in Southeast Asia: Artists and Movements (1997). Examples of Singapore's focus are the exhibitions Modernity and Beyond: Themes in Southeast Asian Art (1996); Visions and Enchantment: Southeast Asian Paintings (2000); and, the recent, very important survey of contemporary South-East Asian art, edited by Iola Lenzi, Negotiating Home, History and Nation: Two Decades of Contemporary Art in Southeast Asia 1991-2011 (Singapore Art Museum, 2011).
} 
partly because of government funding to encourage creative industry and the government's determination to make Singapore a cultural and economic hub in the region. Despite some issues related to censorship, Singapore is helped in this endeavour by having a multicultural society and international trade outlook.

China is now emerging as a strong player in the contemporary art scene with a large number of new museums, including private museums of contemporary art, being established as well as an increasingly full calendar of art fairs and biennales, museum workshops and innovative exhibitions and specialist conferences, as is South Korea. Japan experienced a museum boom from the 1970s, presaging what occurred in mainland China, South Korea, Taiwan and Singapore from the 1990s. While Japan has been an important innovator and initiator of debates for decades, as Japanese scholars have noted, it is still perceived by some as being in an ambiguous position because of Japan's wartime invasions of neighbouring countries in the 1930s and 1940s.

Museums play an important role in initiating new exchanges, but face the dilemma of pursuing a local or international orientation, as Ho demonstrates in his study of the Hong Kong-based M+ museum development. His argument presents the importance of museums connecting to local roots and local histories. The hundreds of new museums and art institutions that now exist, or are being planned, across Asia are a rich resource, providing significant infrastructure and with the potential to be shapers of public culture across the region.

Recent geopolitical changes have led museums, curators and artists in the region to initiate new transnational connections. Some have been pursued as cultural diplomacy initiatives between, for example, Japan and China, India and China and, in 2010, the Palace Museum in Beijing and the National Palace Museum in Taiwan - the latter a collaboration that would have been thought impossible a decade ago. Transnational exchange programs, such as that described by Sambrani, and the programs of Asialink in Australia described by Carroll, have taken on a renewed importance as sites for cross-cultural dialogue and for intraAsian cultural connections.

As Merewether, Hoffie, Sambrani, Meskimmon, Maravillas, Carroll, Ho, Lo and Antoinette show, contemporary artists have been and are engaged with projects of significance beyond their own countries, especially when these relate to issues of social, political and environmental change in the region. The work of Indonesian artist Dadang Christanto, for example, is about legacies and memories of the past, the tragic hidden history of the Indonesian killings of 1965-1966, and also about recent ethnic division within Indonesia, including the killings and rapes of Chinese Indonesians in 1998. As discussed by both 
Hoffie and Meskimmon, Christanto is an example of an artist whose work has been widely seen internationally, especially within Asia, and whose work has significance well beyond Indonesia and Asia. ${ }^{29}$

\section{Australia and Asia}

A key theme of this volume is Australia's connection with Asia, which is explored here and in essays by Hoffie, Carroll, Antoinette, and Lo. I also include here a brief case study of the APT, an Australian museum-based project that exemplifies many of the issues discussed above relating to transformations in approaches to art in the region.
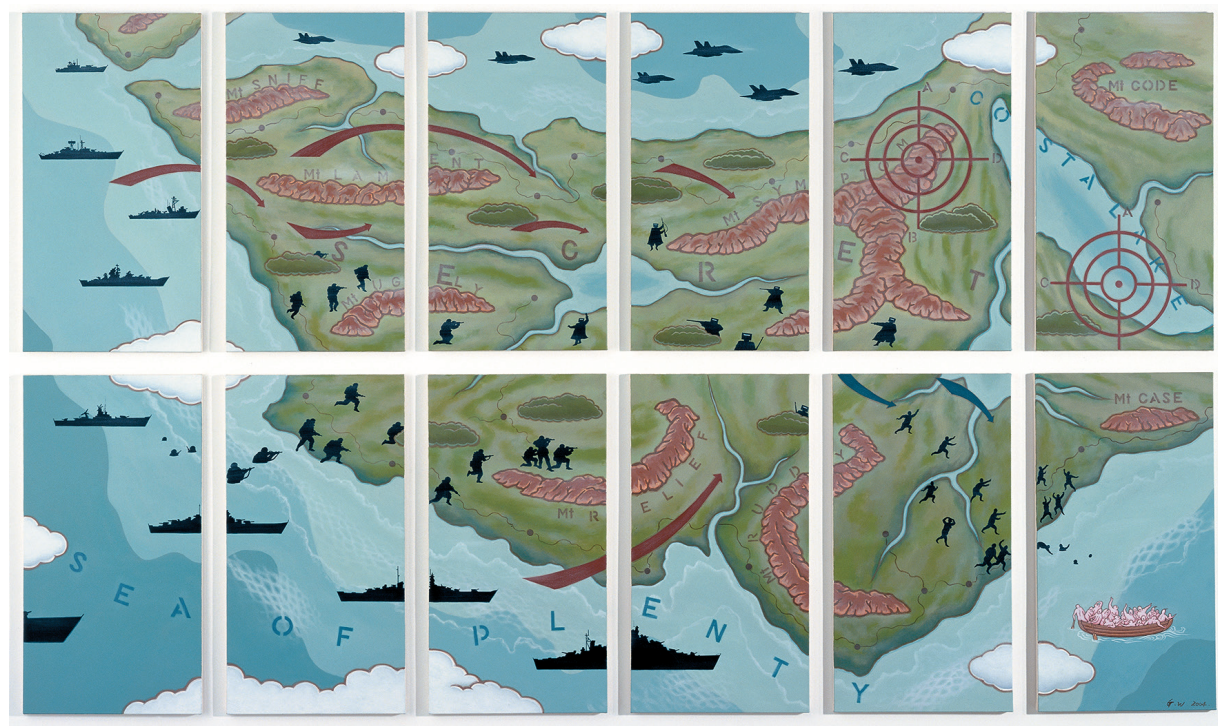

Guan Wei, Where's Ned Kelly? 2004; acrylic on canvas; 180 x 306 cm.

Image courtesy the artist

Australia has a long history of engagement with Asia, but also a long history, I suggest, of clinging to outdated conceptions and stereotypes of the region. Projects such as those of Asialink and the APT, both beginning in the early 1990s, were designed to counter such perceptions through knowledge of contemporary realities, not only of art but of changing societies in Asia.

Australians are not ignorant of Asia. Many Australians have been involved with Asia since the nineteenth century through trade, as travellers and adventurers,

29 See also Caroline Turner and Jen Webb, Art and Human Rights: Contemporary Asian Contexts (Manchester University Press, forthcoming). 
as part of colonial administrations, and as missionaries. Asian immigration to Australia, which began in the nineteenth century with large-scale Chinese immigration, was halted by the mid-nineteenth century adoption of the White Australia policy. This policy was not officially abandoned until 1973. Australian Bureau of Statistics figures estimate that six per cent of the Australian population is Asian born, and Asian-Australians, those of Asian descent, make a major contribution to Australia's economic, political, intellectual and cultural life. ${ }^{30}$ Lo's essay provides a fascinating exploration of the significance of this contribution and Antoinette's essay also discusses the contributions of AsianAustralian artists.

In the twentieth century numerous Australians travelled to Asia, for example as tourists, traders, maritime workers, journalists and diplomats, among others. The Second World War was a turning point in terms of growth in the numbers of Australians serving in Asia in theatres of war. Since then, Australian troops have been involved in the postwar occupation of Japan, the Malayan Emergency, Konfrontasi in Borneo, the Korean and Vietnam wars, Iraq, Afghanistan and, more recently, in peacekeeping roles; for example, in Cambodia and East Timor. Many Asian students began studying in Australia in the 1950s as part of the Colombo Plan, and this has continued more recently with growing numbers of Asian students, self-funded as well as on scholarships, studying at Australian schools and universities. The critical importance of economic ties with Asia is acknowledged by all sides of politics, especially relations with Japan, China, South Korea, India and Indonesia. There has been significant tourism of Australians to Asia and vice versa since the 1980s and considerable reciprocal investment between Asia and Australia, beginning with Japanese investment in the mining industry. Many Australians now work regularly in Asia. An example of expanding ties is the considerable growth in Asian studies courses in Australia, particularly since the Second World War. Asian languages are now taught in schools as well as universities and Asian history, especially Indian history, has long been part of university curricula. Much more, however, needs to be done in the areas of 'Asia literacy', a point frequently made in discussions of Australia's relations with Asia, which include evaluation of competencies required for Australia to engage effectively with Asia in the future in areas such as culture, innovation, science and technology, trade relations and economic endeavours. ${ }^{31}$ While Australians, therefore, have knowledge of Asia, this is sometimes outdated knowledge including, as Carroll notes, in the area of art

\footnotetext{
30 The Australian population is 24 per cent immigrant (2000), a quarter of whom were born in Asia. Between 1981 and 2000 the Asian-born population of Australia grew to 6 per cent. Source: Australian Bureau of Statistics: http://www.abs.gov.au/AUSSTATS/abs@.nsf/2f762f95845417aeca25706c00834efa/666a320ed773 6 d32ca2570ec000bf8f9! OpenDocument.

31 In 2012 the then Labor government released a white paper, Australia in the Asian Century, which examined Australia's relations, including cultural relations, with Asia. An example of developments since the white paper is 'Asia Literacy: Language and Beyond', a two-year national research project, which is part
} 
history. University courses did not focus on the subject of Asian art, especially contemporary Asian art, until the 1990s. Since that decade, art schools and individual artists have been involved with Asia in increasing numbers, with the Canberra School of Art being an early pioneer in establishing links that came to be valuable to the early work of the APT. Artist exchanges since the 1990s have been greatly assisted by Asialink residencies and grants from the Australia Council for the Arts. ${ }^{32}$

Australians have long been exposed to the historical and classical arts of Asia through the collections of Australian art museums that were established in the nineteenth century. Exhibitions of historical Asian culture have had a strong presence in Australian museums since the 1970s. This process has much older precedents, however; indeed, exhibitions of Asian culture were shown in international fairs or exhibitions in Australia in the nineteenth century. In the twentieth century, Asia-content exhibitions became a significant new emphasis in museum and gallery programming from the 1950s onwards. The real exhibition focus on Asia, however, accelerated dramatically with a series of remarkable historical Chinese art exhibitions that were arranged under successive cultural agreements, starting in 1977 with Recent Archaeological Discoveries from the People's Republic of China..$^{33}$ Contemporary Asian art received some attention through initiatives such as the Artists Regional Exchange (ARX) (based in Perth) in the 1980s and the Sydney Biennale, which had shown some Asian artists

of the 'Safeguarding Australia's Future' program of the Australian Council of Learned Academies funded by the Australian Research Council through the Office of the Chief Scientist: http://www.acolasecretariat.org.au/ ACOLA/index.php/projects/securing-australia-s-future/project-3.

32 The Canberra School of Art under David Williams was a pioneer in these exchanges. The Artists Regional Exchange (ARX), which was based in Perth, focused on South-East Asia from 1987 (see Pamela Zeplin, acuads.com.au/conference/2005-conference/article/the-arx-experiment-1987-1999-communities-controversyand-regionality/). Australian art museums began exhibiting and collecting contemporary Asian art in the 1990s. Among the most significant museum initiatives of the 1990s was the series of contemporary Asian art exhibitions commissioned by the new Museum of Contemporary Art (MCA), Sydney, under Leon Paroissien and Bernice Murphy (for example, Mao goes Pop: China post-1989 (1993), curated by Li Xianting \& Nicholas Jose), as well as Post Mao Product: New Art From China (1992) curated by Claire Roberts at the Art Gallery of New South Wales (AGNSW) and which travelled to Ballarat, Canberra and Brisbane. Many Australian institutions have shown contemporary Asian art in recent years. Examples are India Songs: Multiple Streams in Contemporary Indian Art (1993), curated by Victoria Lynn with Indian Commissioners Manjit Bawa and Haku Shah at the AGNSW; Edge of Desire: Recent Art In India (2004-2007), curated by Chaitanya Sambrani and organised by the Asia Society, New York, and the Art Gallery of Western Australia, Perth (the exhibition travelled to Perth, New York, Mexico City, Monterrey, Berkeley, New Delhi and Mumbai); Inside Out: New Chinese Art, curated by Gao Minglu in association with the Asia Society and the San Francisco Museum of Modern Art (the exhibition was shown at the National Gallery of Australia, Canberra, in 2000); Beyond the Self: Contemporary Portraiture from Asia (2011), curated by Christine Clark at the National Portrait Gallery (NPG), Canberra; and Go Figure! Contemporary Chinese Portraiture (2012), curated by Claire Roberts at the NPG and Sherman Contemporary Art Foundation.

33 Turner, 'International Exhibitions', in Understanding Museums, eds Des Griffin and Leon Paroissien (National Museum of Australia: Canberra, 2011), http://www.nma.gov.au/research/understanding-museums/ CTurner_2011.html. 
since the 1970s, although not in great numbers until the late 1990s. In the late 1980s and early 1990s, however, Australia, Europe and North America had limited knowledge of the dynamic contemporary art of the region as a whole.

Asialink, which is discussed by Carroll with a focus on the arts program, has been a critical conduit for Australia's engagement with Asia across a broad range of activities. It was founded in 1990 to 'work with business, government, philanthropic and cultural partners to initiate and strengthen Australia-Asia engagement'. This singularly important body, a joint initiative of the Australian Government's Commission for the Future and the Myer Foundation and, from 1991, a centre of the University of Melbourne, has in the last 20 years developed crucial Australia-Asia connections through business, professional links, health, education and contemporary arts and cultural collaborations, including residencies and exhibitions in 21 countries. The Sydney-based Sherman Gallery, later Sherman Foundation, under Dr Gene Sherman, has been a major private supporter of contemporary Asian Art.

QAG, in the form of the APT, which began in 1993 and of which I was project director in the 1990s, was the first Australian art museum to make a major commitment to the contemporary art of the region (although, later, other Australian art museums began to exhibit and collect contemporary Asian art). ${ }^{34}$ There have been seven APT exhibitions over a period of 20 years to 2012 with a total attendance of over two million visitors. These figures are substantial for exhibitions of contemporary art in a city with a population of just over two million people and in a country with a population of 23 million people. One of the APT's key objectives was to provide a series of exhibitions that could educate Australians about the dynamic changes in contemporary societies in the Asia-Pacific region and, at the same time, connect with emerging debates in the

34 For its first three exhibitions, the APT had a national committee consisting of Doug Hall, director, QAG; Caroline Turner, deputy director, QAG; David Williams, ANU; Alison Carroll, Asialink; Neil Manton, Department of Foreign Affairs and Trade; and Ian Howard, director of the Queensland College of Art. For a recent discussion of the APT see Hoffie, this volume; the catalogues of the first, second, third, fourth, fifth, sixth and seventh APTs, (Brisbane: Queensland Art Gallery, 1993-2012); Caroline Turner \& Rhana Devenport eds, Papers from the Second Asia-Pacific Triennial Conference (Brisbane: Queensland Art Gallery, 1996); Caroline Turner \& Morris Low eds, Beyond the Future: Papers from the Third Asia-Pacific Triennial Conference (Brisbane: Queensland Art Gallery, 1999); Jen Webb, 'The Asia-Pacific Triennial: Synthesis in the Making' (with Tony Schirato), Continuum 14, no. 3 (special issue: Synthesis) (November 2000): 34958; and Turner, 'Cultural Transformations in the Asia-Pacific: The Asia-Pacific Triennial and the Fukuoka Triennale Compared', in Eye of the Beholder: Reception, Audience and Practice of Modern Asian Art, eds John Clark, Maurizio Peleggi \& T.K. Sabapathy, University of Sydney East Asia Series, No 15 (Wild Peony, 2006), 221-43. See also Turner, 'Case Studies: Asia-Pacific - Part A. Asia-Pacific Triennial of Contemporary Art', Yishu Journal of Contemporary Chinese Art 12, no. 3 (May/June, 2013): 37-43 and 'Selected Reading on Contemporary Asian Art' and especially essays by Anthony Gardner \& Charles Green, 'Mega-Exhibitions, New Publics, and Asian Art Biennials', in Art in the Asia-Pacific: Intimate Publics, eds Larissa Hjorth, Natalie King \& Mami Kataoka (New York and London: Routledge, 2014), 23-36; Russell Storer, 'Dots in the Domain: The Asia Pacific Triennial of Contemporary Art', in Hjorth, King \& Kataoka, 37-48; and references in Hoffie's essay, this volume. For a regional perspective see Sabapathy, 'Developing Regionalist Perspectives', 13-17. A full evaluation of the contributions of the APT from a regional perspective is overdue. 
region and outside Asia about the nature of contemporary art in a globalising world. The APT's aim in 1993 was thus to provide a forum for discussion of diverse practices, for experimentation, and an intellectual platform for the presentation of local and regional perspectives. The exhibitions provided this platform at a time when there were few biennales or forums for debate about Asian contemporary art anywhere in the world. Many of the participants from the region met for the first time at the first APT exhibitions and conferences in the 1990s.

The APT is regionally focused on the art of Asia, Australia, and the Pacific, but excluding the Americas. As Hoffie notes, this scope encompasses provision for the representation of indigenous cultures from Australia and the Pacific. The definition of Asia-Pacific is not fixed and has included diaspora artists and, more recently, artists from countries of west Asia, such as Afghanistan and Iran. The APT also has an extensive acquisition and commissioning program, which has led to QAG building one of the world's most broadly based collections of contemporary Asian and Pacific art.

It is perhaps difficult for younger scholars and curators today to appreciate that, in the early 1990s, the APT was regarded as a radical project. To that point, contemporary art from Asia and the Pacific (except for Japan) was rarely seen in major international exhibitions. QAG had undertaken an exchange exhibition of contemporary Japanese art in the 1980s, which I negotiated. This proved to be an influential model for the later APT. QAG also showed, in 1992, Australia's first contemporary Chinese touring exhibition, which was curated by Claire Roberts. The most distinctive features of the early APTs in the 1990s were that artists and scholars in the region helped select, curate and write about the art; that the region was defined broadly; that the exhibitions served also to build a collection and archive; and that the art chosen for exhibition was not 'officially' selected. Iftikhar Dadi, the US-based academic and artist, has described the project as significant, noting that in the first decade to 1999 the APT 'emerged as a key force in formulating an understanding of emergent practices in much of the Asian region'. ${ }^{35}$

The first three APT exhibitions showed 220 artists from the region who were chosen by cross-cultural curatorial teams from 20 regional countries, including Australia. While this model changed after 2002, as a concept it helped build new networks and challenged outdated orthodoxies in Australia, where art was seen from mainly Western perspectives. Particularly important were three major associated conferences held in 1993, 1996 and 1999-some of the largest art conferences ever held in Australia and with speakers from the region and

35 Iftikhar Dadi, 'Reflections on the First Decade', in Contemporary Visual Art+Culture Broadsheet 42 (4 December 2012): 266. 
beyond. From the first APT it became apparent that Euro-American discourses needed to be challenged. Importantly, the APT maintained a strong emphasis on art related to issues facing communities in an era of rapid social, political, and technological change and on issues of social justice and environmental degradation.

The large curatorial teams and the numbers of catalogue writers for the first three APT exhibitions, while vital to building networks and knowledge, were subject to some criticism at a time when the accepted wisdom was that one curator should provide the vision for an exhibition. The APT was shaped by collaborations between QAG and hundreds of experts and artists, from many different countries in the region and especially by the intellectual and artistic input of the artists, many of whom came to Australia for the exhibitions. This is not to say that cross-cultural curating does not pose challenges, but the many cross-cultural curatorial engagements that have occurred in the region since the early 1990s, including as part of the APT, the Fukuoka exhibitions and Japan Foundation projects cited in this essay, as well as many other regional initiatives, are generally considered to have been foundational in developing the new approaches to art exhibitions that are now emerging.

In the 1990s more Australian institutions began to develop programs to connect to contemporary art in Asia. The projects of Asialink have been critical in this respect. Another example is the Brisbane-based Media Art Asia Pacific (MAAP), which is the only organisation in the world to focus on new media art in the region and which, since its founding in 1998, has undertaken a large number of collaborative projects in Asia and Australia. ${ }^{36}$

As Lo notes, Asian-Australians have played a significant role in forming and maintaining Australia's connections with Asia. Senior artists, such as William Yang and John Young, who are among the founding members of the AsianAustralian artists' association, 4A, in Sydney, exemplify this influence. Today, $4 \mathrm{~A}$ is a major site of art exchange between Asia and Australia. Lo, Maravillas and Sambrani, three of the authors in this volume, are examples of Asian-Australian academics whose work has contributed greatly to Australian intellectual life and, in recent years, many highly talented and distinguished artists from Asia have immigrated to Australia, such as Nusra Qureshi (Pakistan), Dadang Christanto (Indonesia), Guan Wei (China) and filmmaker Khin Mar Mar Kyi (Burma).

In Part 2 of this Introduction, Antoinette takes up the four key themes of our book in depth, indicating how each contribution relates to those themes and to the conclusions drawn from this volume.

\footnotetext{
36 http://www.maap.org.au/about-maap/. These projects include 'Light from Light' at the Shanghai Library, Hangzhou Library, National Art Museum of China (NAMOC), Beijing and in Brisbane.
} 


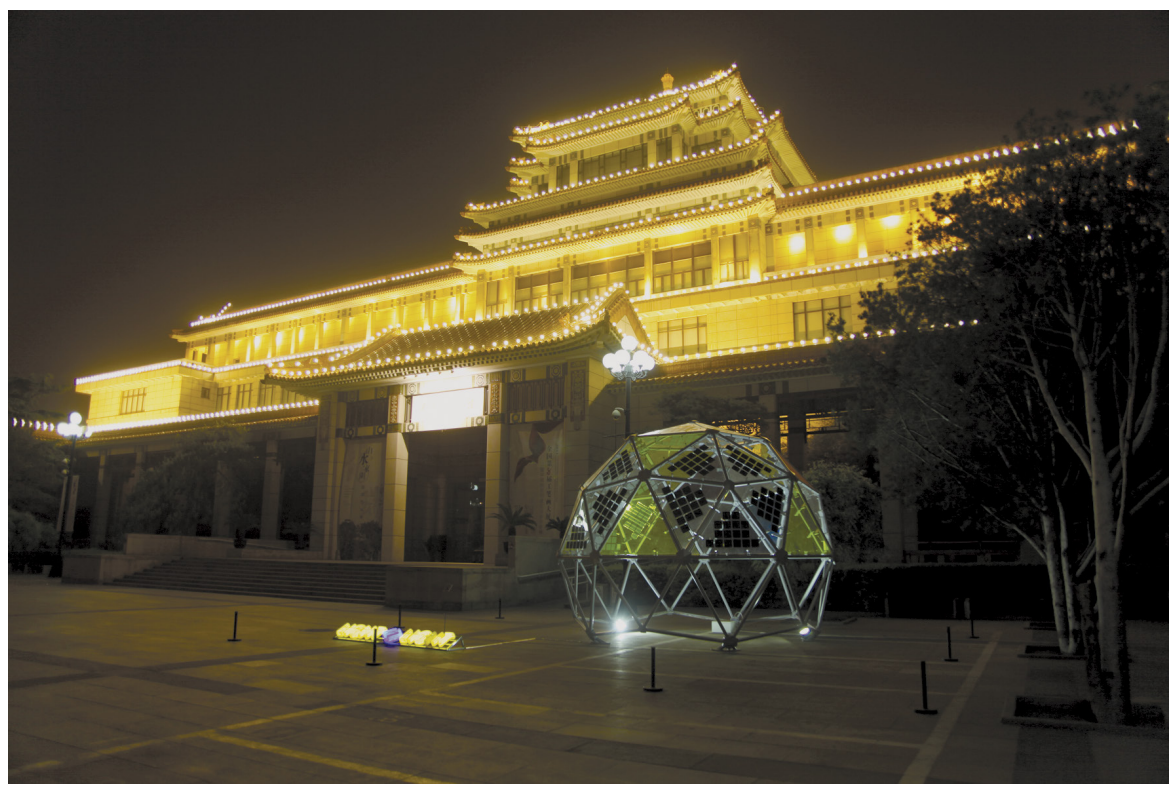

Janet Burchill and Jennifer McCamley, 'Light from Light' 2010; National Art Museum of China (NAMOC), Beijing; self-powered geodesic dome, custom-built photovoltaic panels, acrylic, neon and aluminium frame. Part of collaborative MAAP-Media Art Asia Pacific project by Australian and Chinese artists in Beijing, Shanghai Library, Hangzhou Library and in Brisbane, with the theme of light-inspired and light-generating artworks.

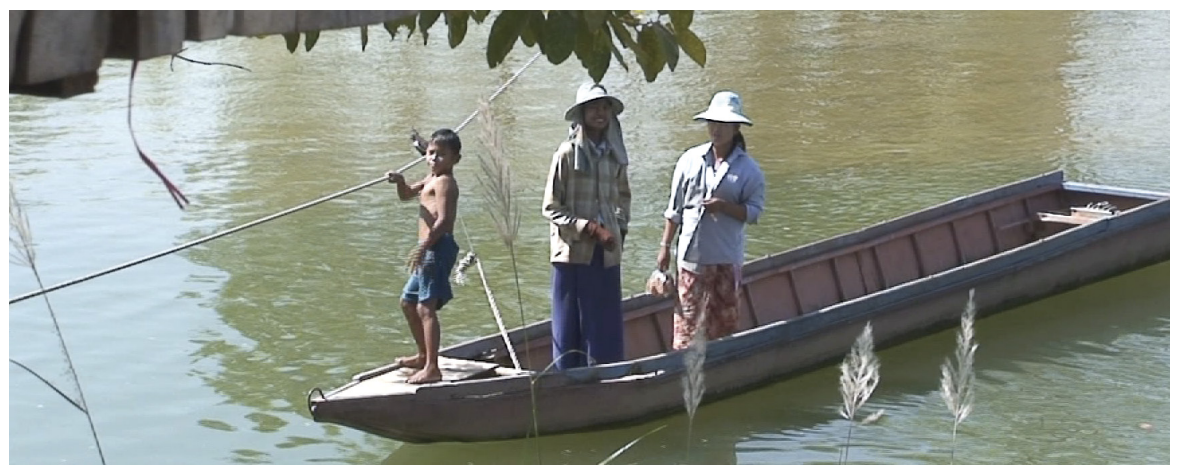

Khin Mar Mar Kyi (filmmaker), Dreams of Dutiful Daughters 2011 (film still). The film is about Burmese women who are illegal immigrants to Thailand. In seeking a better life to support their families, many have been forced into prostitution to survive. This film has been shown to Aung San Suu Kyi and, since the reforms in 2011, to ministers in the government. 
This text taken from Contemporary Asian Art and Exhibitions: Connectivities and world-making, by Michelle Antoinette and Caroline Turner, published 2014 by ANU Press, The Australian National University, Canberra, Australia. 